\title{
Molecular Docking and Identification of Candidate Blockers for Endonuclease Domain of Lassa Virus Polymerase as Potential Drugs
}

\author{
*MINARI, JB; AGHO, EE; ADEBIYI, FD; ROTIMI, OO; SHOLAJA, BO; \\ ADEJUMO, J
}

Department of Cell Biology and Genetics (Cancer and Infectious Research Group Laboratory), Faculty of Science, University of Lagos, PMB 1, Akoka, Yaba, Nigeria

*Corresponding Author Email: author-jminari@unilag.edu.ng

\begin{abstract}
Lassa fever is a deadly hemorrhagic disease virus caused by Lassa virus (LASV) which is a member of the Arenaviridae virus family. Lassa virus-encoded L polymerase is required for the replication and transcription of the RNA virus. There is no available vaccine as ribavirin remains the only treatment provided it is administered in the early stages of infection. This study aims at searching for possible durg candidates that can compare favourably well with ribavirin or possibly exhibit a better potency against the virus. The computational modeling method of docking was performed with AutoDock 4.2. Bioavailability test and Toxicological prediction using Swiss ADME, Toxtree version 2.6.6 and pkCSM softwares. The result obtained from this investigation revealed that some of the selected inhibitors considered in this investigation such as $\alpha$ pinene, $\beta$ pinene, limonene, monoterpene, 6-gingerol showed binding energy of -4.32 kcalmol-1, -4.30 kcalmol-1, -4.25 kcalmol-1, -3.87 kcalmol-1 and - 3.48 kcalmol-1 respectively compete favouarably with that of ribavirin (-4.39kalmol-1) which was considered as standard while the inhibition constant $(\mathrm{Ki})$ of the interaction between the target and that $\alpha$ pinene $(681.86 \mu \mathrm{M}), \beta$ pinene $(768.90 \mu \mathrm{M})$ and limonene $(706.53 \mu \mathrm{M})$ was low when compared others except for ribavirin. The ADME analysis (Lipinski's rule) of the selected Inhibitors predicted all the investigated inhibitors satisfied the Lipinski's rule. It was discovered that the toxicity prediction of selected inhibitors using Toxtree and pkCSM showed that they are less toxic and considered safe for usage. This study, therefore, reveals that $\alpha$ pinene, $\beta$ pinene, limonene promises to be a possible drug candidate as it has the inhibitory potential against Lassa virus L polymerase comparable to ribavirin, bioavailable and less toxic.
\end{abstract}

\section{DOI: https://dx.doi.org/10.4314/jasem.v25i11.8}

Copyright: Copyright $(\odot) 2021$ Minari et al. This is an open access article distributed under the Creative Commons Attribution License (CCL), which permits unrestricted use, distribution, and reproduction in any medium, provided the original work is properly cited.

Dates: Received: 22 August 2021; Revised: 17 September 2021; Accepted: 06 October 2021

Keywords: Lassa virus, inhibitors, polymerase, bioavailability, toxicity

Among the several neglected tropical diseases which cause loss of life and negatively impact the economy of some parts of Africa countries, especially Nigeria is Lassa fever where it is endemic. Lassa virus (LASV), a human hemorrhagic pathogen is the causative agent of Lassa fever. Lassa virus belongs to a member of the Arenaviridae family. The other members of this family include viruses carried by mammalian and reptilian hosts, classified as Mammarenavirus genus, and Reptarenavirus (Maes, et al., 2018). LASV is transmitted mainly by contact with infected rodents (Mastomys spp.) that is particularly predominant in some African countries such as Nigeria. The infection has averagely 10 days' incubation period and this is typically accompanied by general flu-like symptoms, including fever, malaise, and headache. In severe lassa fever conditions, Hemorrhagic and/or neurologic conditions have been linked to the infection (Basler, 2017). It was documented that about 500,000 infections and nearly 5000 mortality happens yearly with the death rates which can be up to $50 \%$ in cases of hospitalized patients, $90 \%$ in women in their last month of pregnancy and almost $100 \%$ mortality in fetuses (Ogbu, et al 2007). Nigeria has in recent times experienced remarkably great seasonal Lassa fever outbreak which also occurred in 2020 amid the COVID-19 pandemic. This occurrence has in no small measure underscored the importance why the virus should be regarded as a major public health concern in West Africa (Tambo et al., 2018). Lassa fever has been considered lately by the World Health Organization as a priority disease for urgent research and development (WHO, 2018). LASV is a negative-sense RNA genome virus. It consists of two different singlestranded segments ( $\mathrm{S}$ and $\mathrm{L}$ ). $\mathrm{S}$ segments is responsible for the encoding nucleoprotein (NP) as well as precursor for glycoprotein complex (GPC) which is the virus envelop. The $\mathrm{L}$ segment encodes the viral $\mathrm{RdRp}$ and a matrix protein $(\mathrm{Z})$ which helps for viral assembly and budding (Mateer, et al., 2018). 
Nucleoprotein is the most prevalent viral protein both in virions and infected cells, and plays critical roles during arenavirus life cycle. LASV replicates in the cytoplasm of the host cell. The key player during viral genome replication and transcription is the $\sim 250-\mathrm{kDa}$ viral $\mathrm{L}$ protein (endonuclease domain of Lassa virus $\mathrm{L}$ Polymerase). The central domain of the $200-\mathrm{kDa}$ Lassa virus $\mathrm{L}$ polymerase which is required for viral RNA replication and transcription is a putative RNAdependent RNA polymerase. Previous studies have identified endonuclease domain of Lassa virus L Polymerase as a potential drug target due to its significant role in viral replication and transcription. Even though a lot of efforts have been put in the development of new vaccine, there is still no licensed vaccine and only limited treatment options (ribavirin) are being used for the treatment of the disease. Ribavirin which has been useful needs to be administered at the early stages of infection for it to be effective against the virus thus limiting its utility (McCormick et al., 1986; Branco et al., 2010). Therefore, the need to search for more effective drugs which can be administered at any stage of lassa various infection becomes very imperatives. Most new drugs have been known to be developed mainly from natural products. In this study, some bioactive components obtained from natural sources such as $\alpha$ pinene, $\beta$ pinene, limonene, monoterpene, 6-gingerol, 8gingerol, 10-gingerol and Rivabirin were considered for possible inhibition on the endonuclease domain of Lassa virus L Polymerase. $\alpha$ - and $\beta$-pinene are isomers mainly found in nature such as in pine, essential oils. The two isomers ( $\alpha$ - and $\beta$-pinene ) are well known members of the broad family of monoterpenes which is found mainly in essential oils and are known to be widely distributed in the plant kingdom. Earlier report documented that they have several pharmacological properties (Kozioł, et al., 2014). Limonene is another selected inhibitor chosen for this study. It is majorly found in oils recovered from some Citrus plants and useful in the cosmetic industry, drug production, sweetener in some foods, fragrance in soaps and perfumes (Merve et al., 2018). Gingerols are homologous phenolic ketones which representatives the major bioactive compounds found in ginger and they occur as 6, 8, and 10-gingerols with various lengths of their unbranched alkyl chains (Masuda et al., 2004). They have been reported to possess anticancer properties against gastric and colon cancer in vitro (Jeong et al., 2009) and skin cancer in vivo (Katiyar, et al., 1996). Previously, Ribavirin which a guanosine analogue has been an effective antiviral agent against several RNA and DNA viruses and has been reported to efficiently suppress the replication of LASV in vitro (Oestereich et al., 2016). To achieve this, computer based modeling approach was adopted to screen compounds for their inhibitory potential using molecular docking method. Application of computer-based modeling approaches has lately in no significant measure helped in resolution of alot scientific research problems such as drug discovery (Forli et al., 2016). Even though sometimes the result obtained could differ slightly from experiment outcome it has severally served as a link between experimental and theoretical sciences with high level of precision. This study was therefore carried out to screen for inhibitory potential of the selected compounds for endonuclease domain of Lassa virus L Polymerase which could be further studied for possible development as drugs for Lassa Virus fever.

\section{MATERIALS AND METHOD}

Receptor and Ligands Selection: Ligand selected for this investigation were retrieved from PubChem (https://pubchem.ncbi.nlm.nih.gov/) which selections was based on chemical formula and physiochemical properties (Kim et al., 2015). In order to elucidate the binding sites of the ligands (inhibitors) on the target molecule, 3D-structure of endonuclease domain of Lassa virus L Polymerase was downloaded from RCSB-PDB (https://www.rcsb.org/\#Categorysearch).

Preparation of Receptor and Ligands: The preparation for docking of the ligands and the receptor was carried out as described by Scholz et al., 2015 which leads to the removal of water molecules and other sites on endonuclease domain of Lassa virus L Polymerase structure. This will help to enhance the interaction of selected inhibitors or ligands with the receptor. In preparation of the ligand for docking, the Gasteiger charge was assigned and then non-polar hydrogens were merged since the ligands considered are not peptides like ligand. Therigid roots of each ligand used were also defined automatically rather than picking them manually.

Molecular Docking: Inhibitors used in this investigation were optimized structures from Discovery Studio (DS) 2.1 (Accelrys Software, Inc., San Diego) (Venkatachalam et al., 2003), (Gowthaman et al., 2008), (Hariprasad et al., 2010). The 3D structure of endonuclease domain of Lassa virus L Polymerase was retrieved from the Protein Data Bank (Natesh et al., 2003). In this investigation, moleculear docking of Lassa virus $\mathrm{L}$ Polymerase with $\alpha$ pinene, $\beta$ pinene, limonene, monoterpene, 6-gingerol, 8-gingerol, 10 -gingerol was done by different computational tools, with the aim to discover the best inhibitor, which ultimately would provide the basis for designing drugs against 
Lassa virus infection by inhibiting endonuclease domain of Lassa virus L Polymerase. To get the best conformers, Lamarckian genetic algorithm was used in this study and a maximum of 10 conformers were considered for each compound. Each ligand has their primary position on the box and randomly focused. Autodock Tool Kit (ADT) which is linked with Autodock 4.2 was used to set the parameters for the study. AutoDock 4.2 was used for docking of the ligands on the endonuclease domain of Lassa virus L Polymerase receptor. The components of the program involved in the study are AutoGrid and AutoDock. AutoGrid using the AMBER force field was used to calculate the $3 \mathrm{D}$ grid of interaction energies.

Absorption, Distribution, Metabolism, and Excretion (ADME) Analysis: Swiss Institute of Bioinformatics, Switzerland (SwissADME) was used to predict the Drug-likeness of our allicin (Daina and Zoete, 2016). The absorption of the $\alpha$ pinene, $\beta$ pinene, limonene, monoterpene, 6-gingerol, 8-gingerol, 10 -gingerol in the brain, skin permeation and gastrointestinal tract was predicted using Brain or IntestinaL EstimateD permeation predictive model (BOILED-Egg) which has a threshold (WLOGP $\leq 5.88$ and TPSA $\leq 131.6$ ). This reveals a $2 \mathrm{D}$ graphical representation in which the yolk area represents the molecules that can passively be absorbed by the blood-brain barrier (BBB) while the molecules located in the white region are predicted to be passively cross into the gastrointestinal (GI) tract.

Prediction of Toxicity: Toxtree version 2.6.6 (http://toxtree.sourceforge. net /) and pkCSM ( http://biosig.unimelb.edu.au/pkcsm) are the softwares used for the prediction of the tocixicity of the ligand considered in this study. The 2D structures of the inhibitors, $\alpha$ pinene, $\beta$ pinene, limonene, monoterpene, 6-gingerol, 8-gingerol, 10 -gingerol were screened for toxicity using Toxtree and pkCSM. The values chosen in Toxtree were Cramer rule, Kroes TTC decision tree, carcinogenicity (genotox and non genotox) mutagenicity rule base by ISS, and in vitro mutagenicity (Ames test) alerts by ISS. The chosen value in pkCSM were Ames Toxicity, Maximum Tolerated Dose, Rat Acute Oral Toxicity (LD50) and hepatotoxicity.

\section{RESULTS AND DISCUSSION}

Table 1 reveals docking analysis of Lassa virus $\mathrm{L}$ Polymerase with some selected compounds with their binding free energy, inhibition constant, torsional and electrostatic energy and ligand efficiency. Some of the selected inhibitors considered in this investigation such as $\alpha$ pinene, $\beta$ pinene, limonene, monoterpene, 6 gingerol showed binding energy of -4.32 kcalmol-1, 4.30 kcalmol-1, -4.25 kcalmol-1, -3.87 kcalmol-1 and - 3.48 kcalmol-1 respectively compared favouarably with that of rivabirin $(-4.39 \mathrm{kalmol}-1)$ which was considered as standard in(Table I). The inhibition constant $(\mathrm{Ki})$ of the interaction between the target and selected compounds demonstrated that $\alpha$ pinene $(681.86 \mu \mathrm{M})$, beta pinene $(768.90 \mu \mathrm{M})$ and limonene $(706.53 \mu \mathrm{M})$ was low when compared with others except for rivabirin (table 1). The torsional energy, electrostatic energy and ligand efficiency of values of $\alpha$ pinene, beta pinene and limonene also compares favourably with rivabirin (table 1). Analysis of the selected inhibitors using BOILED-Egg method of $\mathrm{ADME}$ is revealed in figure 2. It revealed GI absorption and BBB penetration. However, $\alpha$ pinene, $\beta$ pinene, limonene, monoterpene, 6-gingerol are predicted as the nonsubstrates of P-glycoprotein while 8-gingerol and 10-gingerol were predicted to be actively effluxed by P-glycoprotein. The ADME analysis (Lipinski's rule) of the selected Inhibitors is revealed in table 2 . This shows the parameters such as molecular weight $(\mathrm{g} / \mathrm{mol})$, lipophilicity $(\mathrm{MLogP}), \mathrm{H}-$ bond donor and $\mathrm{H}$-acceptors of the inhibitors studied. 10-gingerol has the highest molecular weight $(350.49 \mathrm{~g} / \mathrm{mol})$ while limonene and $\alpha$ pinene has the lowest with $136.23(\mathrm{~g} / \mathrm{mol})$. $\alpha$ pinene and beta pinene has highest Lipophilicity values (4.29) while lowest values were for 6-gingerol (2.14). The highest values of $\mathrm{H}$-bond donor and $\mathrm{H}$-acceptors which are 2 and 4 respectively were observed for 6-gingerol, 8-gingerol and 10-gingerol.

\begin{tabular}{llllll}
\multicolumn{5}{c}{ Table1: Docking Analysis of Lassa virus L Polymerase with some selected inhibitors } \\
\hline Inhibitors & $\begin{array}{l}\text { Binding Free } \\
\text { Energy } \\
(\mathrm{Kcal} / \mathrm{mol})\end{array}$ & $\begin{array}{l}\text { Inhibition } \\
\text { Constant } \\
(\mathrm{Ki})\end{array}$ & $\begin{array}{l}\text { Torsional } \\
\text { Energy } \\
(\mathrm{Kcal} / \mathrm{mol})\end{array}$ & $\begin{array}{l}\text { Electrostatic } \\
\text { Energy } \\
(\mathrm{Kcal} / \mathrm{mol})\end{array}$ & $\begin{array}{l}\text { Ligand } \\
\text { Efficiency }\end{array}$ \\
\hline Monoterpene & -3.87 & $1.45 \mathrm{mM}$ & 0.06 & -0.21 & -0.35 \\
\hline Limonene & -4.25 & $706.53 \mu \mathrm{M}$ & 0.00 & -0.01 & -0.43 \\
\hline$\beta$-pinene & -4.30 & $768.90 \mu \mathrm{M}$ & 0.03 & -0.03 & -0.43 \\
\hline 10 -gingerol & -2.43 & $16.69 \mathrm{mM}$ & -0.62 & 4.77 & -0.10 \\
\hline 8 -gingerol & -1.25 & $122.21 \mathrm{mM}$ & 4.18 & -0.27 & -0.05 \\
\hline 6 -gingerol & -3.48 & $2.84 \mathrm{mM}$ & 3.52 & 0.03 & -0.17 \\
\hline$\alpha$ pinene & -4.32 & $681.86 \mu \mathrm{M}$ & 0.00 & -0.01 & -0.43 \\
\hline Ribavirin & -4.39 & $600.55 \mu \mathrm{M}$ & +1.79 & -1.01 & -0.26 \\
\hline
\end{tabular}




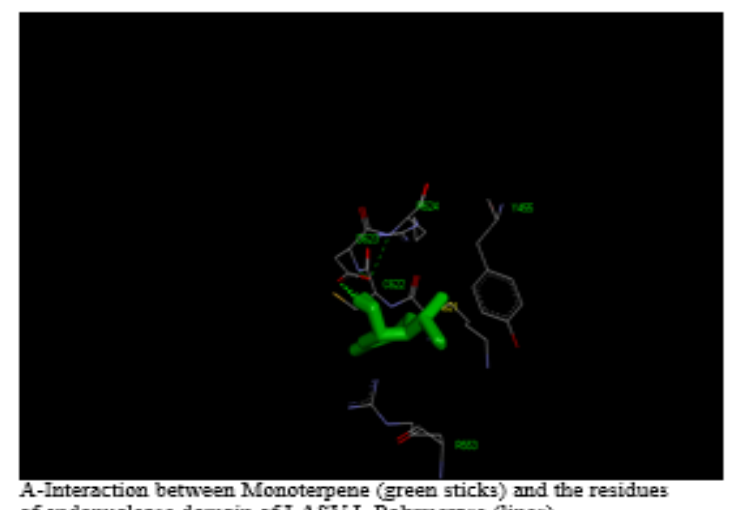

of endonuclease domain of LASV L Polymerase (lines)

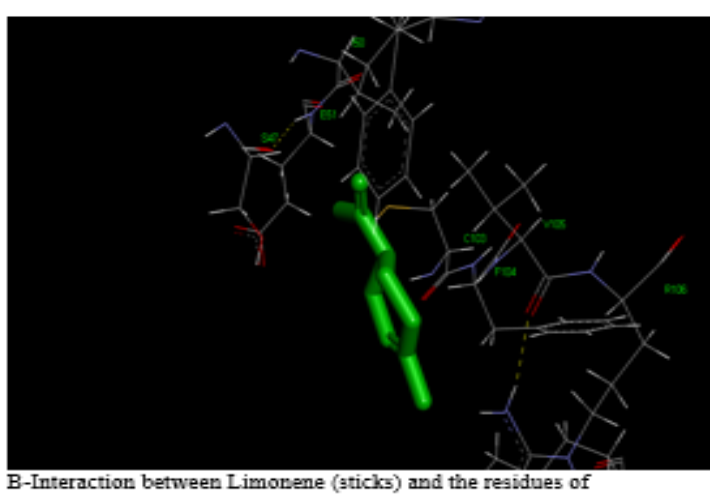
residues of endonuclease domain of L.ASV L Polymerase (lines)

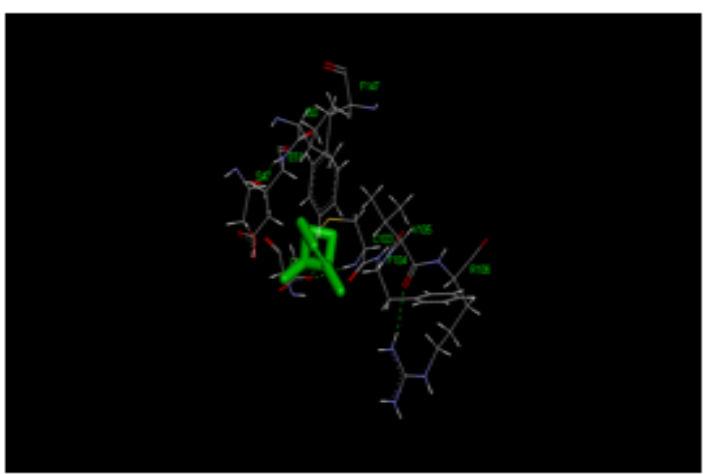

C-Interaction between $\beta$-pinene (green sticks) and residues of endonuclease domain of LASV L Polymerase (lines)

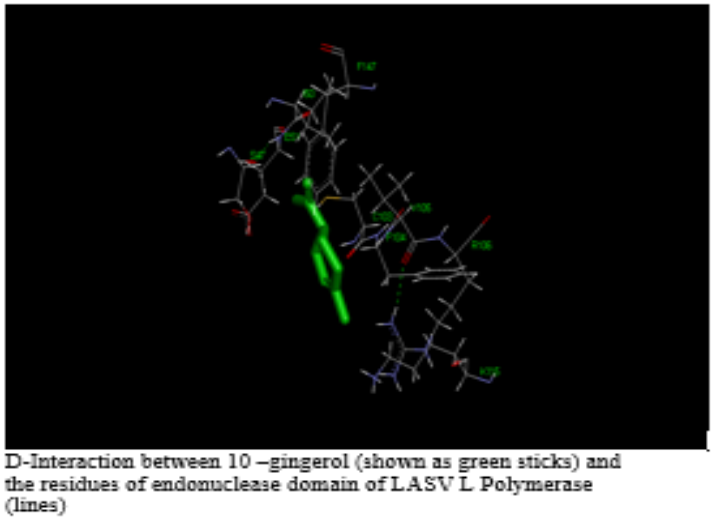

Plates 1A-D: Docking complex of endonuclease domain of LASV L Polymerase with some selected Inhibitors

Table 3 shows pharmacokinetics parameters of selected inhibitors. It reveals the pharmacokinetics parameters of the of the compounds considered in this investigation. The $\alpha$-pinene, $\beta$ pinene and limonene showed skin permeation with $-3.96(\mathrm{~cm} / \mathrm{s}),-4.18$ $(\mathrm{cm} / \mathrm{s})$ and $-3.89(\mathrm{~cm} / \mathrm{s})$ respectively, "Yes" for all blood brain barrier and a low GI absorption. The toxicity prediction of the selected inhibitors using toxtree and pkCSM is shown in table 4. The results from this study showed Cramer rule to be low for all the inhibitors. The Kroes TTC revealed that the inhibitors studied are not expected to be a safety concern. Carcinogenicity was negative for all compounds investigated while there were no mutagenicity and hepatotoxicity for all inhibitors as well.

Monoterpene has the highest value at the maximum daily dose endpoint of $0.809 \mathrm{mg} / \mathrm{kg} /$ day and 10 gingerol has the highest value of LD50 endpoint of $2.601 \mathrm{~mol} / \mathrm{kg}$. 10-gingerol has the lowest value at the maximum daily dose endpoint of $-0.237 \mathrm{mg} / \mathrm{kg} / \mathrm{day}$ and Monoterpene has the lowest value of LD50 endpoint of $1.723 \mathrm{~mol} / \mathrm{kg}$. Lassa fever outbreak in countries such as Nigeria has led to several loss of lives and has negatively impacted the economy. Although drugs like Ribavirin has been beneficial but not without a huge limitation of being effective only on useage at early stages of infection. In the search for a better option, this study was carried out to identify inhibitors which could stop the replication of the virus at any stage thereby serving as a potential drug compound using molecular docking. Several parameters such as the binding energy, inhibition constant, torsional energy, electrostatic energy and ligand efficiency were used to assess inhibitory potential of the compounds. Also assessed were bioavailability and safety parameters. The binding energy of all the compound considered in this investigation (-4.32 kcalmol-1, -4.30 kcalmol-1, 4.25 kcalmol-1, -3.87 kcalmol-1 and - 3.48 kcalmol-1) compared favourably with that of rivabirin (4.39kalmol-1) and this suggests that they are inhibitors which contain the potential endonuclease domain of Lassa virus L Polymerase inhibitory binding sites comparable to that of the rivabirin used as standard. Rivabirin is one of the few drugs known to be very effective in treating lassa virus fever which must be administered early (Carrillo-Bustamante et al., 2017). Ribavirin is a guanosine analogue displaying broad antiviral activity against several RNA and DNA viruses which efficiently suppresses the replication of LASV in vitro (Oestereich, et al., 2016). The antiviral activity of ribavirin has suggested to be effect in its interaction with the viral RNA polymerase which utilizes ribavirin triphosphate 
thereby mutagenizing the genome and decreasing the yield of infectious virus (Crotty, et al., 2000). Hence the reason for the use as a standard in this study. The inhibition constant $(\mathrm{Ki})$ reflects the binding affinity of compounds or inhibitors to the target molecules. The smaller the $\mathrm{Ki}$, the greater the binding affinity and the smaller amount of medication needed in order to inhibit the activity of that the target molecule. The values of $\mathrm{Ki}$ of these inhibitors compared favourably with that of rivabirin considered as standard in this study. This implies that $\alpha$ pinene, $\beta$ pinene and limonene are more effective inhibitors of Lassa virus L Polymerase than other compound considered in this study and could possibly be good drug candidates for lassa virus fever. The values of torsional energy, electrostatic energy and ligand efficiency for $\alpha$ pinene, beta pinene and limonene which competes favourably with rivabirin (table 1), further laid credence to earlier assertions in this study that these three inhibitors could be further studied for LASV fever possible therapy. The variation values of binding energy, inhibition constant, torsional energy, electrostatic energy and

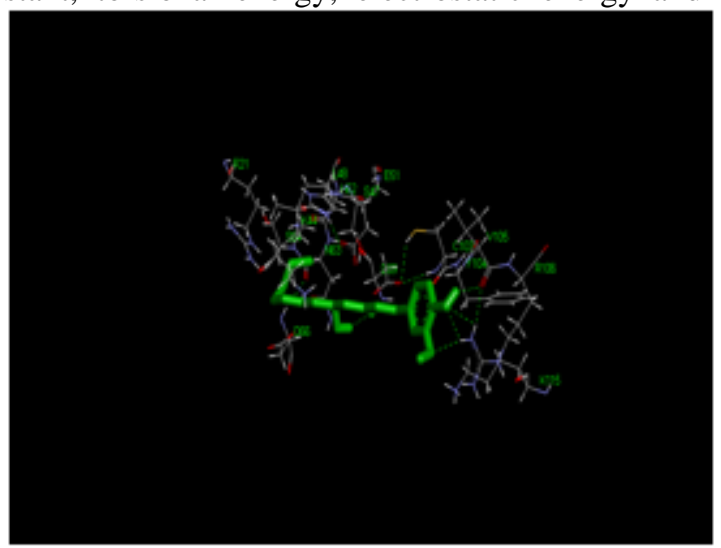

E-Interaction between 8 -gingerol (shown as green sticks) and residues of endonuclease domain of L.ASV L Polymerase (lines)

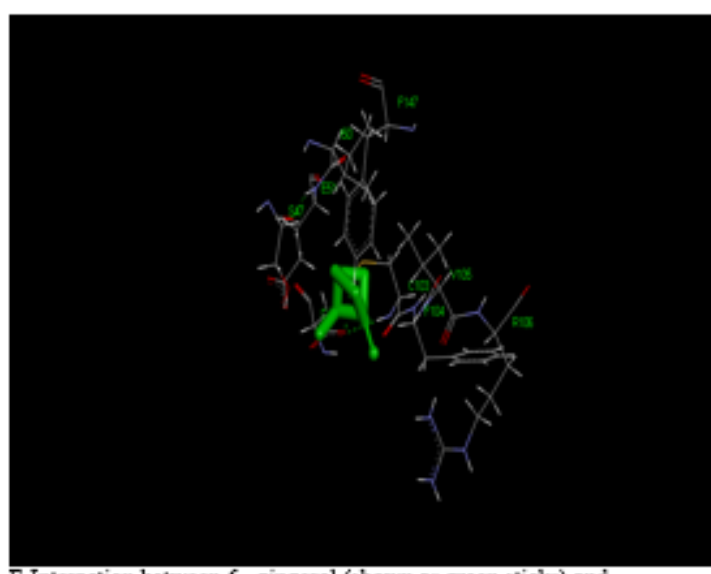

F-Interaction between 6 -gingerol (ghown as green sticks) and residues of endonuclease domain of LASV L Polymerase (lines) ligand efficiency of $\alpha$ pinene, $\beta$ pinene and limonene observed in this investigation when compared with ribavirin could be attributed to the differences in the position of the functional groups on the inhibitors. Different functional groups on the selected inhibitors have demonstrated variation in binding pattern, energy and efficiency to the Lassa virus L Polymerase (plates $1 \mathrm{~A}-\mathrm{H})$. This observation agrees with similar reports by Umamaheswari et al., 2011. Although most of the selected inhibitors investigated in this docking study especially $\alpha$ pinene, $\beta$ pinene and limonene showed effective inhibitory potential against lassa virus $L$ polymease, this does not guarantee the appropriateness as a remedy. Therefore, it is necessary to use BOILED-Egg model and ADME analysis of inhibitors which helps to provide authentication of inhibitor for possible drug development (Lipinski, 2004). The BOILED-Egg model helps in the computation of polarity and lipophilicity of derivatives as it gives datasets with accuracy, speed, and clear graphical outputs (Daina et al., 2016).

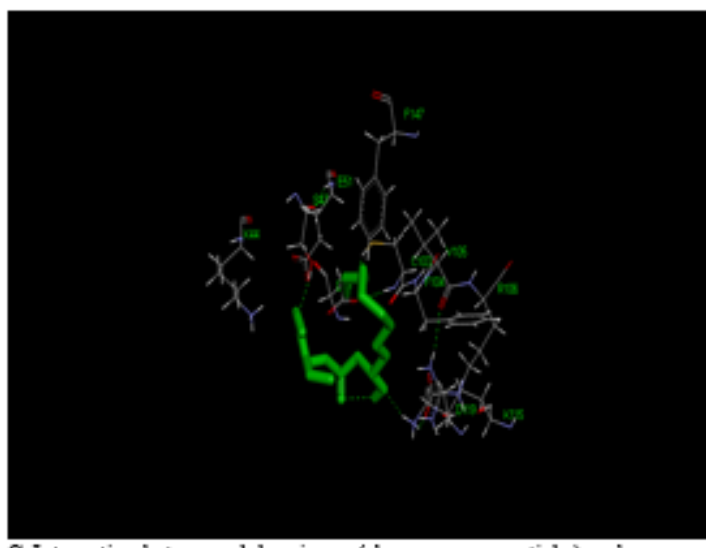

G-Interaction between alpha pinene (shown as green sticks) and residues of ndonuclease domain of L.ASV L Polymerase (lines)

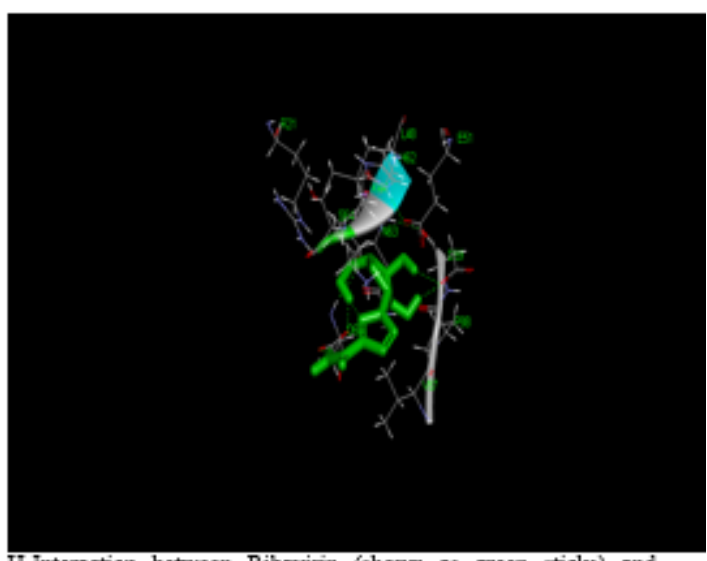

H-Interaction between Ribavirin (skown as green sticks) and residues of endonuclease domain of LASV L Polymerase (lines)

Plates 1E-H: Docking complex of endonuclease domain of LASV L Polymerase with some selected Inhibitors 


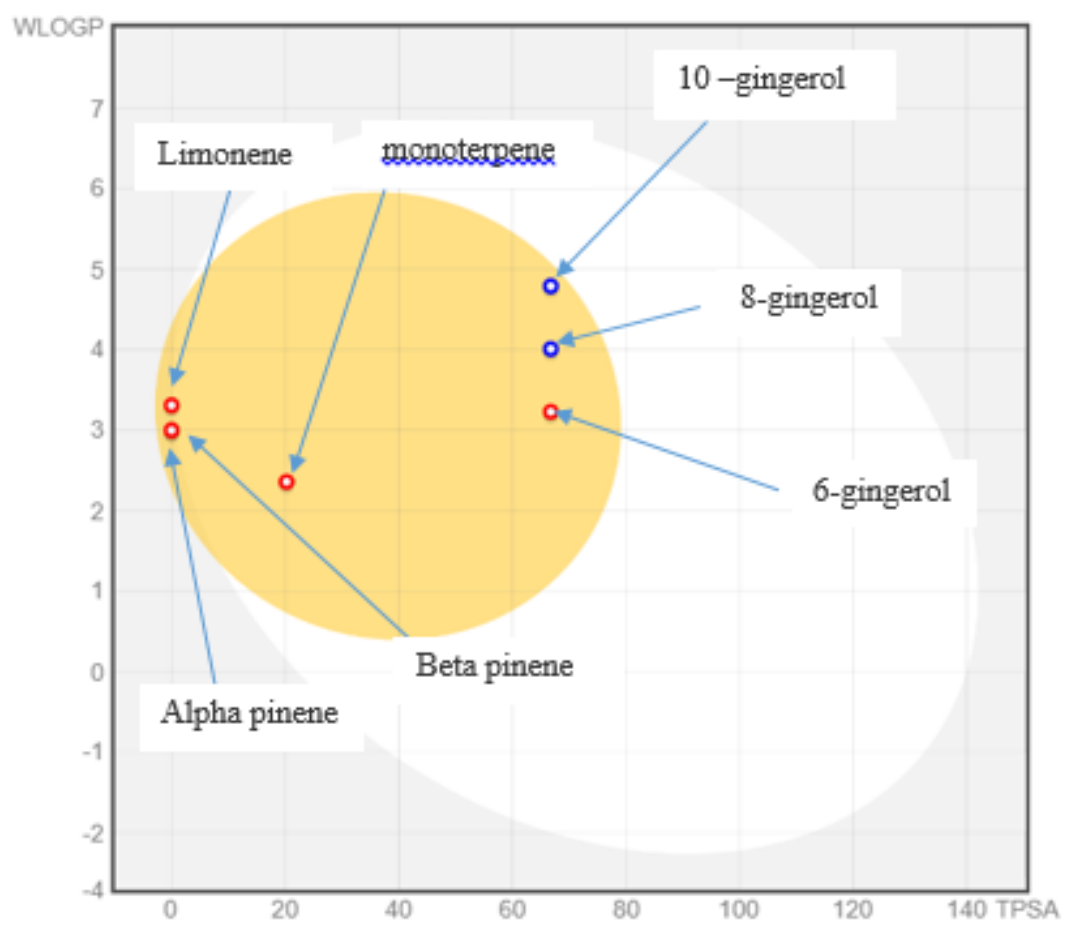

Fig 2: Analysis of the selected inhibitors using BIOLED-EGG method of ADME

The passive absorption of the GI tract is denoted by the white region, while the yellow region (yolk) denotes the high possibility of the BBB penetration. Also, the blue coloured molecule represents actively effluxed by P-glycoprotein while the red coloured molecule indicates the nonsubstrate of P-glycoprotein. In this study, even though the pharmacokinetics parameters of the three promising drug candidates $(\alpha$ pinene, $\beta$ pinene and limonene) showed skin permeation and a low GI absorption (table 4), BOILED-Egg analysis predicted that all the inhibitors investigated (figure 2) revealed GI absorption and BBB penetration. However, $\alpha$ pinene, $\beta$ pinene, limonene, monoterpene, 6-gingerol are predicted as the nonsubstrates of P-glycoprotein while 8-gingerol and 10-gingerol were predicted to be actively effluxed by P-glycoprotein. This investigation reveals that the three earlier mentioned inhibitors in this study ( $\alpha$ pinene, $\beta$ pinene and limonene) which showed inhibitory potential against lassa virus L polymerase could be absorbed by gastrointestinal tract and bloodbrain barrier within the acceptable range.

This results obtained from the SwissADME analysis (table 2) represents parameters of Lipinski's rule of five also known as Pfizer's rule of five Lipinski, 2016). This provides information on the degree of the oral bioavailability of a compound. Good bioavailability will satisfy the Lipinski rule where the maximum molecular weight of the compound is 500, the $\log \mathrm{P}$ is not greater than 5 , the hydrogen bond donor is less than 5, and hydrogen bond acceptor is less than 10 (Lipinski et al., 2012). All the investigated inhibitors in this study satisfy the Lipinski's rule.

\begin{tabular}{|c|c|c|c|c|}
\hline Inhibitors & $\begin{array}{l}\text { Molecula } \\
\mathrm{r} \\
\text { Weight } \\
(\mathrm{g} / \mathrm{mol})\end{array}$ & $\begin{array}{l}\text { Lipophilicit } \\
\mathrm{y} \\
(\mathrm{MLogP})\end{array}$ & $\begin{array}{l}\mathrm{H}- \\
\text { bond } \\
\text { dono } \\
\mathrm{r}\end{array}$ & $\begin{array}{l}\text { H-bond } \\
\text { acceptor } \\
\text { s }\end{array}$ \\
\hline $\begin{array}{l}\text { Monoterpen } \\
\text { e }\end{array}$ & 154.25 & 2.30 & 1 & 1 \\
\hline limonene & 136.23 & 3.27 & 0 & 0 \\
\hline$\beta$-pinene & 136.23 & 4.29 & 0 & 0 \\
\hline 10 -gingerol & 350.49 & 3.06 & 2 & 4 \\
\hline 8 -gingerol & 322.44 & 2.61 & 2 & 4 \\
\hline 6 -gingerol & 294.39 & 2.14 & 2 & 4 \\
\hline$\alpha$ pinene & 136.23 & 4.29 & 0 & 0 \\
\hline
\end{tabular}

Table 3: Pharmacokinetics Parameters of Selected Inhibitors

\begin{tabular}{llll}
\hline Inhibitors & $\begin{array}{l}\text { Gastro } \\
\text { Intestinal } \\
\text { Absorption }\end{array}$ & $\begin{array}{l}\text { Blood } \\
\text { Brain } \\
\text { Barrier }\end{array}$ & $\begin{array}{l}\text { Skin } \\
\text { Permeation } \\
\left(\log K_{P}\right) \\
(\mathrm{cm} / \mathrm{s})\end{array}$ \\
\hline Monoterpene & High & Yes & -5.73 \\
\hline Limonene & Low & Yes & -3.89 \\
\hline$\beta$-pinene & Low & Yes & -4.18 \\
\hline $10-$ gingerol & High & Yes & -4.70 \\
\hline $8-$ gingerol & High & Yes & -5.29 \\
\hline 6 -gingerol & High & Yes & -6.14 \\
\hline$\alpha$ pinene & Low & Yes & -3.95 \\
\hline
\end{tabular}




\begin{tabular}{|c|c|c|c|c|c|c|c|}
\hline $\begin{array}{l}\text { Toxicity } \\
\text { Parameter }\end{array}$ & Monoterpene & Limonene & $\beta$-pinene & 10-gingerol & 8-gingerol & 6-gingerol & $\alpha$-pinene \\
\hline Cramer Rule & Low & Low & Low & Low & Low & Low & Low \\
\hline Kroes TTC & $\begin{array}{l}\text { Not } \\
\text { expected to } \\
\text { be a safety } \\
\text { concern }\end{array}$ & $\begin{array}{l}\text { Not expected } \\
\text { to be a safety } \\
\text { concern }\end{array}$ & $\begin{array}{l}\text { Not } \\
\text { expected to } \\
\text { be a safety } \\
\text { concern }\end{array}$ & $\begin{array}{l}\text { Not } \\
\text { expected to } \\
\text { be a safety } \\
\text { concern }\end{array}$ & $\begin{array}{l}\text { Not expected } \\
\text { to be a safety } \\
\text { concern }\end{array}$ & $\begin{array}{l}\text { Not expected } \\
\text { to be a safety } \\
\text { concern }\end{array}$ & $\begin{array}{l}\text { Not } \\
\text { expected to } \\
\text { be a safety } \\
\text { concern }\end{array}$ \\
\hline $\begin{array}{l}\text { Carcinogenicity } \\
\text { (genetox) }\end{array}$ & Negative & Negative & Negative & Negative & Negative & Negative & Negative \\
\hline $\begin{array}{l}\text { Carcinogenicity } \\
\text { (non-genetox) }\end{array}$ & Negative & Negative & Negative & Negative & Negative & Negative & Negative \\
\hline $\begin{array}{l}\text { In vitro } \\
\text { Mutagenicity }(A M \\
E S \text { test })\end{array}$ & NO & $\mathrm{NO}$ & $\mathrm{NO}$ & $\mathrm{NO}$ & $\mathrm{NO}$ & NO & NO \\
\hline $\begin{array}{l}\text { Mutagenicity } \\
\text { pkCSM }\end{array}$ & NO & NO & NO & NO & NO & NO & NO \\
\hline $\begin{array}{r}\text { Max daily dose } \\
\text { (Log } \mathrm{mg} / \mathrm{kg} / \text { day) }\end{array}$ & 0.809 & 0.770 & 0.577 & -0.237 & -0.028 & 0.205 & 0.480 \\
\hline $\begin{array}{l}\text { Rat Acute Oral } \\
\text { Toxicity } \mathrm{LD}_{50} \\
\text { (mol/kg) }\end{array}$ & 1.723 & 1.880 & 1.761 & 2.601 & 2.472 & 2.368 & 1.770 \\
\hline Hepatotoxicity & NO & $\mathrm{NO}$ & NO & $\mathrm{NO}$ & NO & $\mathrm{NO}$ & NO \\
\hline
\end{tabular}

This suggested that inhibitors especially $\alpha$ pinene, $\beta$ pinene and limonene has the high bioavailability properties. It has earlier been documented that compound with lower molecular weight, $\log \mathrm{P}$, hydrogen bond donor, and hydrogen bond acceptor has the higher bioavailability (Veber et al., 2002) and good absorptivity for an oral medication (Wulandari and Kristin, 2010). According to the results obtained from Toxicity Prediction of Selected Inhibitors Using Toxtree and pkCSM, the Cramer rule Toxtree shows that all the inhibitors are of class 1 (score 1). This means that the inhibitors have a low toxicity risk. Kroes TTC endpoint shows that the inhibitors are not expected to be of safety concern and hence guaranteed for the safety in their use. The carcinogenicity (genotoxic and non-genotoxic) of $\alpha$ pinene, $\beta$ pinene, limonene, monoterpene, 6-gingerol, 8-gingerol, 10gingerol, are negative. This suggests that the inhibitors do not have the tendency to cause irreversible genetic damage or mutations by binding to DNA and nongenotoxic carcinogenesis. The in vitro mutagenicity (Ames test) also predicted that all the inhibitors have no risk as mutagen. The mutagenicity endpoint of pKCSM confirms non-mutagenicity of the inhibitors. This study also showed the possible maximum daily dose endpoint of the good drug candidates ( $\alpha$ pinene, $\beta$ pinene, and limonene) $0.480 \mathrm{mg} / \mathrm{kg} / \mathrm{day}, 0.577$ $\mathrm{mg} / \mathrm{kg} /$ day and $0.77 \mathrm{mg} / \mathrm{kg} /$ day. Their LD50 endpoint were also revealed as $1.770 \mathrm{~mol} / \mathrm{kg}, 1.761 \mathrm{~mol} / \mathrm{kg}$ and $1.880 \mathrm{~mol} / \mathrm{kg}$. The hepatotoxicity (pkCSM) test also revealed that the inhibitors are non-hepatotoxic compounds. The study showed that $\alpha$ pinene, $\beta$ pinene, and limonene exhibited effective inhibitory potential for Lassa virus L polymerase as much as ribavirin which is one of the most effective drugs being used for Lassa virus fever. Bioavailability investigation and toxicity prediction showed that the inhibitors are good drug candidates and are safe for consumption if considered for future remedy. Further study needs to be carried out on the inhibitors both in vitro and in vivo.

\section{REFERENCES}

Basler, CF (2017). Molecular pathogenesis of viral hemorrhagic fever. Semi Immunopathol. 39: 551561.

Branco, LM; Grove, JN; Geske, FJ; Boisen, ML; Muncy, IM; Magliato, AS; Henderson, LA; Schoepp, RJ; Cashman, KA; Hensley, LE; Garry, RF (2010). Lassa virus- like particles displaying all major immunological determinants as a vaccine candidate for lassa hemorrhagic fever. $J$. Virol. 20:277- 279

Carrillo-Bustamante, P; Nguyen, TY; Oestereich, L; Günther, S; Guedj, J; Frederik G (2017). Determining Ribavirin's mechanism of action against Lassa virus infection Sci. Rep. 7: 11693

Crotty, S; Maag, D; Arnold, JJ; Zhong, W; Lau, JY; Hong, Z., Andino, R; Cameron, CE 2000. The broad-spectrum antiviral ribonucloeside ribavirin is an RNA virus mutagen. Nat. Med. 6: 1375-1379

Daina, A; Zoete, VA (2016). BOILED-Egg To Predict Gastrointestinal Absorption and Brain Penetration of Small Molecules. ChemMedChem. 11: 1117-1121

Forli, S; Huey, R; Pique, ME; Sanner, MF; Goodsell, DS; Olson, AJ (2016). Computational Protein- 
ligand Docking and virtual drug screening with the autodock suite. Nat. Protoc. 11: (5): 905-919

Gowthaman, U; Jayakanthan, M; Sundar, D; (2008). Molecular docking studies of dithionitrobenzoic acid and its related compounds to protein disulfide isomerase: computational screening of inhibitors to HIV-1 entry. BMC Bioinformatics. 9: S14.

Hariprasad, G; Kumar, M; Srinivasan, A; Kaur, P; Singh, TP; (2010). Structural analysis of a group III Glu62-phospholipase A2 from the scorpion, Mesobuthustamulus: targeting and reversible inhibition by native peptides. Int. J. Bio. Macromol. 48(3): 423-431.

Jeong, CH; Bode, AM; Pugliese, A; Cho, YY; Kim, HG; Shim, JH; Jeon, YJ; Li, H; Jiang, H; Dong Z; (2009). Gingerol suppresses colon cancer growth by targeting leukotriene A4 hydrolase. Cancer Res. 69:5584-5591.

Katiyar, SK; Agarwal, R; Mukhtar, H (1996). Inhibition of tumor promotion in SENCAR mouse skin by ethanol extract of Zingiberofficinale rhizome. Cancer Res. 56:1023-1030.

Kim S; Thiessen PA; Bolton EE; Chen J; Fu G; Gindulyte A; Han L; He J; He S; Shoemaker B.A. (2015). PubChem substance and compound databases. Nucleic Acids Res. 44: D1202-D1213

Lipinski CA; Lombardo F; Dominy B. W., Feeney P. J. (2012). Experimental and computational approaches to estimate solubility and permeability in drug discovery and development settings. Adv. Drug Deliv. Rev. 64, 4-17.

Lipinski, CA (2016). Rule of five in 2015 and beyond: Target and ligand structural limitations, ligand chemistry structure and drug discovery project decisions. Adv. Drug Deliv. Rev. 101:34-41.

Lipinski, CA (2004). Lead-and drug-like compounds: The rule-of-five revolution . Drug Discov. Today Technol. 1:337-341.

Madeswaran, A; Umamaheswari, M; Asokkumar K; Sivashanmugam, T; Subhadradevi, V; Jagannath, P; (2011). Docking studies: In silico lipoxygenase inhibitory activity of some commercially available flavonoids. Bangladesh J. Pharmacol. 6: 117-23.
Maes, P; Alkhovsky, SV; Bao, Y; Beer, M; Birkhead, $\mathrm{M}$; Briese, T; Buchmeier., MJ; Calisher, $\mathrm{CH}$; Charrel, RN; Choi, IR (2018). Taxonomy of the family Arenaviridae and the order Bunyavirales. Arch. Virol. 163: 2295-2310.

Masuda, Y; Kikuzaki, H; Hisamoto, M; Nakatani, N; (2004) Antioxidant properties of gingerol related compounds from ginger. Biofactors. 21:293-296.

McCormick, JB; King, IJ; Webb, PA; Scribner, CL; Craven, RB; Johnson, KM; Elliot, LH; BelmontWilliams R (1986). Lassa fever effective therapy with ribavirin. $N$ Engl J. Med. 314: 20-26.

Merve, BA; Ahmet BN (2018). Effects and Usage of a Citrus Compound, Limonenein Polyphenols: Prevention and Treatment of Human Disease (Second Edition), $484 \mathrm{p}$

Natesh, R., Schwager, S.U., Sturrock, E.D. and Acharya, K. R. (2003). Crystal structure of the human angiotensin-converting enzyme-lisinopril complex. Nature. 421:551-554.

Oestereich, L; Rieger, T; Ludtke, A; Ruibal, P; Wurr, S; Pallasch, E; Bockholt, S; Krasemann, S; Munor- Fontela, C; Gunther, S (2016). Efficacy of favipiravir alone and in combination with ribavirin in a lethal, immunocompetent mouse model of Lassa fever. J. Infect. Dis. 213(6) :934938.

Ogbu, O; Ajuluchukwu, E; Uneke, CJ (2007). Lassa fever in West African sub-region: An overview 2007. J. Vector Borne Dis. 44:1-11.

Scholz, N; Gehring, J; Guan, C; Ljaschenko, D; Fischer, R; Lakshmanan, V; Kittel, RJ; Langenhan, T. (2015). The Adhesion GPCR Latrophilin/CIRL Shapes Mechanosensation. Cell Rep. 11(6): 866--874.

Sliwoski, G; Kothiwale, S; Meiler, J; Lowe, EW (2014). Computational Methods in Drug Discovery. Pharmacol. Rev. 66 (1): 334-395

Tambo, E; Oluwasegun, T; Adetunde, O; Olalubi, OA (2018). Re-emerging Lassa Fever outbreaks in Nigeria: Re- enforcing "One Health" community surveillance and emergency response practice. Infect. Dis. Poverty. 28 (7:) 37

Veber, DF; Johnson, SR; Cheng, H; Smith, BR; Ward, KW; Kopple, KD (2012). Molecular properties 
that influence the oral bioavailability of drug candidates. J. Med. Chem. 26: 15-23

Venkatachalam, C; Jiang, X; Oldfield, T; Waldman, M (2003). LigandFit: a novel method for the shape-directed rapid docking of ligands to protein active sites. J. Mol. Graph. Model. 21:289-307

World Health Organization (WHO) 2018. Recommended Surveillance Standard https://www.who.int/csr/resources/publications/s urveillance/whocdscsrisr992.pdf Accessed August 2020
World Health Organization (WHO) 2020. Lassa Fever in Nigeria. https://www.who.int/csr/don/20february-2020-lassa-fever-nigeria/en/. Accessed August 2020

Wulandari and Kristin E. (2010). Analisis interaksi histone deacetylase (HDAC) kelas ii homo sapiens dengan suberoyllanilide hydroxamic acids (saha) dan trichostatin a (tsa). tesis, depok: fakuitas matematika dan ilmu pentgetahuan Alam UI. https://www.library.ui.ac.id. Accessed August 2020. 